Limnol. Rev. (2021) 21, 1: 3-13

DOI 10.2478/limre-2021-0001

\title{
Responses and Tolerance Mechanisms of Mangrove Trees to the Ambient Salinity along the Egyptian Red Sea Coast
}

\author{
Abdelwahab A. Afefe ${ }^{1 *}$, Abdel-Hamid A. Khedr ${ }^{2}$, Mohamed S. Abbas ${ }^{3}$, Amira Sh. Soliman ${ }^{3}$ \\ ą Nature Conservation Sector, Egyptian Environmental Affairs Agency (EEAA), \\ e-mail. abdoafefe@hotmail.com *(corresponding author) \\ Botany and Microbiology Department, Faculty of Science, Damietta University, Egypt \\ łNatural Resources Department, Faculty of African Postgraduate Studies, Cairo University.
}

\begin{abstract}
Due to the importance of mangrove forests to the ecological system, environment, climate change adaptation, mitigation and ecosystem services, it is necessary to understand the status of the mangroves in Egypt (ecology and physiology). The present study aimed to obtain the basic information needed to evaluate the photosynthetic pigments and proline mechanisms of Avicennia marina and Rhizophora mucronata mangrove to the ambient salinity. The results reached that the free proline accumulated appreciably in leaves. The functional role of proline accumulation appears to be as a cytoplasmic osmoticum to lower cell water potential, provide hydration to bipolymer and serve as an energy source under high salinity environmental conditions. Mangroves showed variations in proline content between the two species. The highest value of proline was recorded 23.56 $\mathrm{mg} / \mathrm{g}$ dry wt for $R$. mucronata and the minimum value was recorded $17 \mathrm{mg} / \mathrm{g}$ dry wt for $A$. marina. In addition, the mean value of proline was recorded $18.57 \mathrm{mg} / \mathrm{g}$ dry wt for $A$. marina and $23.98 \mathrm{mg} / \mathrm{g}$ dry wt for $R$. mucronata. The contents of chlorophyll-a in different analyzed mangroves was ranged from 4.46 to $6.05 \mathrm{mg} / \mathrm{gf}$.wt. for $A$. marina, and from 3.69 to $4.29 \mathrm{mg} / \mathrm{gf}$.wt. for $R$. mucronata. In addition, the chlorophyll-b content was ranged from 1.46 to $1.83 \mathrm{mg} / \mathrm{gf}$.wt. for $A$. marina, and from 1.27 to 1.65 $\mathrm{mg} / \mathrm{gf}$.wt. for $R$. mucronata. The carotenoids contents in mangroves ranged from 2.94 to $2.29 \mathrm{mg} / \mathrm{gf}$.wt for $A$. marina and from 2.04 to $2.09 \mathrm{mg} / \mathrm{gf}$.wt for $R$. mucronata. In the present study, A. marina was relatively more tolerant and adapted to salinity, low rainfall and extreme temperature conditions than $R$. mucronata. This explains the more significant local distribution of $A$. marina in Egypt compared to R. mucronata.
\end{abstract}

Key words: Mangrove, Red Sea, Avicennia marina, Rhizophora mucronata, Salinity, Osmotic adaptation

\section{Introduction}

Mangrove forests are tropical trees and woody shrubs growing at the intertidal zone of the highly productive ecosystem of the tropical and subtropical regions (Kathiresan \& Bingham 2001). These forests cover approximately 137,760 $\mathrm{km}^{2}$ worldwide (Giri et al. 2011). They are highly productive forests that have adapted to survive in the harsh interface between land and sea (Spalding et al. 2010). The mangrove forests distributed along tropical and subtropical coasts are an important ecosystem because of their high net ecosystem production and carbon reserves (Komiyama et al. 2008; Poungparn et al. 2012). The mangroves provide coastal protection, habitat, shelter, nursery and breeding grounds for many fish, crustacea, and other sea and terrestrial fauna (Alongi et al. 2004). They constitute typical brackish water vegetation in the tropics, where the mixing of freshwater and seawater occurs (Karsten 1891). Mangroves grow in a broad range of salt concentrations including freshwater (Bowman 1917) and under extreme environmental and climatic conditions such as high salinity, temperature and radiation (Moorthy and Kathiresan 1999). According to Lugo (1980), mangroves are facultative halophytes; i.e., they can often survive, though not necessarily thrive, in non-saline habitats. It is reported that the growth of many halophytes is depressed without $\mathrm{NaCl}$ in the external 
environment (Greenway \& Munns 1980). Limited amounts of $\mathrm{NaCl}$ are required in the external medium for the maximum growth of the mangroves, while the interstitial water salinity are important to the growth rate, survival rate and zonation of mangrove species (Aksornkoae 1993). Mangrove species continuously incorporate salts from the substrate and transport them to the leaves in the transpiration stream (Ball 1988). The salt uptake helps to maintain positive pressure potential through its contribution to osmotic adjustment of growing tissues (Suárez \& Sobrado 2000). However, under high salinity conditions, the survival of the plant depends on its ability to regulate the internal salt concentrations and prevent reaching toxic levels (Ball 1988). Mangroves are long-day plants and require a high intensity of full sunlight and they may experience periods of intense physiological stress when high temperatures are combined with full sunlight and prevailing winds, which can give rise to high evapotranspiration and increased surface salinity due to capillary uptake (Aksornkoae 1993). Free proline accumulation is one of the most frequently reported metabolic modifications induced by different stresses in plants and despite this, the precise role of proline in plants' stress physiology, as well as the metabolic adjustments associated with its biosynthesis, remains a matter of controversy $(\mathrm{Gi}-$ bon et al. 2000). The mangroves in Egypt occupy about $\mathbf{5 2 5}$ hectares (ha) distributed in $\mathbf{2 8}$ different locations along the Egyptian Red Sea coast (Zahran \& Willis 2009). Mangroves in Egypt are predominantly monospecific, consisting only of Avicennia marina (grey mangroves; Avicenniaceae); except for a few locations near the Egyptian-Sudanese border area, where Rhizophora mucronata (loop-root mangrove; Rhizophoraceae) coexists along with $A$. marina (PERSGA 2004). Afefe et al. (2020) reported that the average biomass per hectare of the Egyptian mangroves was 74997.1 and $22536.8 \mathrm{~kg}$ for A. marina and $R$. mucronata, respectively and they estimated organic carbon content for the Egyptian mangroves (525 ha) was $17.73 \mathrm{Gg} \mathrm{C}$ for biomass and $5.97 \mathrm{Gg} C$ year ${ }^{-}$, for soil: a total of $23.7 \mathrm{Gg}$ C. The present study aimed to investigate biochemical responses (photosynthetic pigments and proline mechanisms) of Avicennia marina and Rhizophora mucronata to salinity conditions affecting mangroves in the Gebel Elba Protected Area along the Egyptian Red Sea Coast.

\section{Material and methods}

\section{Study Area}

Gebel Elba Protected Area is a part of the Egyptian deserts that is considered as one of the most extreme arid areas of the world and located between the longitudes $22^{\circ} 00^{\prime} \mathrm{N}-23^{\circ} 50^{\prime} \mathrm{N}$, and the latitudes $35^{\circ} 00^{\prime} \mathrm{E}-37^{\circ} \mathrm{O} 0^{\prime} \mathrm{E}$, with a total area of about $35,600 \mathrm{~km}$. The area recorded $11.4 \mathrm{C}^{\circ}$ during January for mean minimum temperature and $38.7 \mathrm{C}^{\circ}$

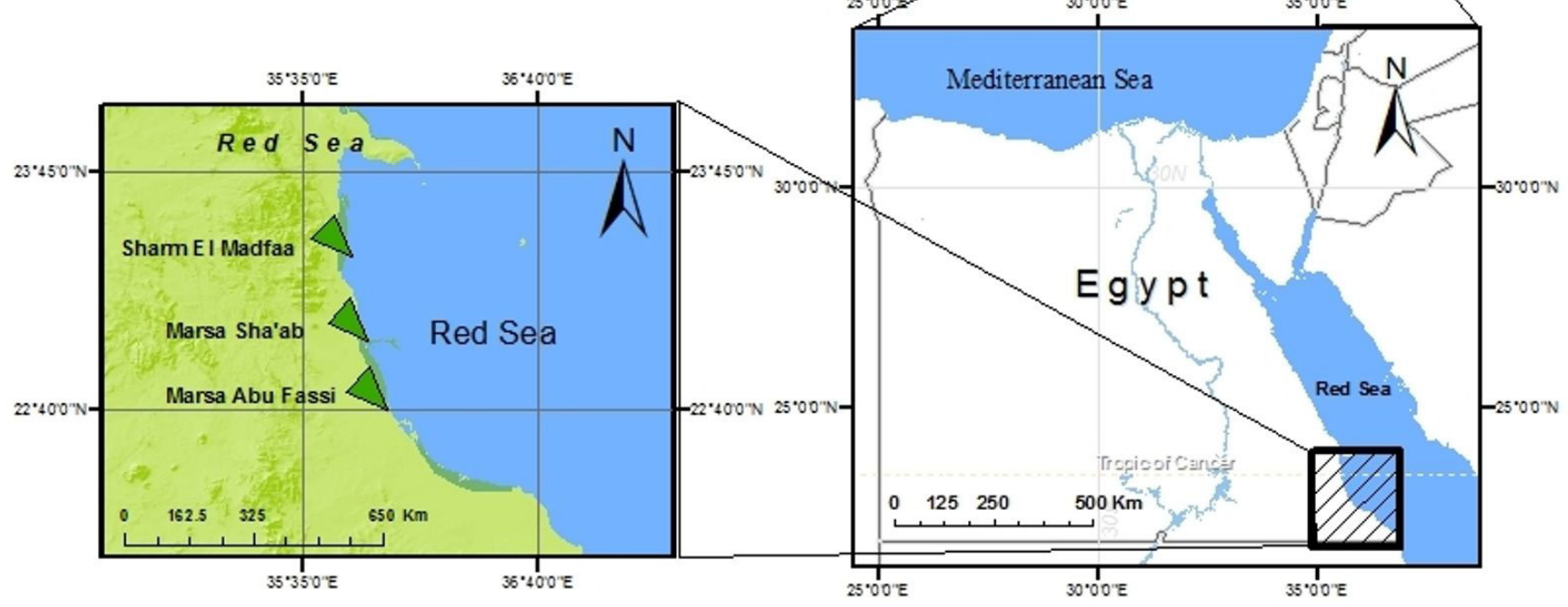

Fig 1. Map of Egypt with focusing on Gebel Elba Protected Area showing the study sites 
in July for maximum temperature (GEPA 2008). Mangroves stands were sampled from June 2016 to June 2017. At the three main locations, 24 sites were selected to represent the mangroves forests at the Egyptian-African Red Sea Coast. The field sites were located south of Shalateen city to the north of Abu Ramad village (Figure 1). Sharm El Madfaa (9.2 $\left.\mathrm{km}^{2}\right)$, Marsa Sha' ab $\left(15.8 \mathrm{~km}^{2}\right)$ and Marsa Abu Fassi $\left(0.7 \mathrm{~km}^{2}\right)$ (ITTO 2006). Mangroves species composition at each location was determined (either $A$. $m a-$ rina or $R$. mucronata).

\section{The Study Species}

The mangroves stands along the Gulf of Aqaba and the Egyptian Red Sea coastlines cover a total area exceeding 525 hectares (Zahran \& Willis 2009). They are predominantly monospecific, consisting only of Avicennia marina, except for a few stands in the southern Sudanese border area where Rhizophora mucronata coexists along with Avicennia marina. From a geographical point of view, the Egyptian mangroves may be divided into the Sinai mangroves and mangroves growing on the Egyptian Red Sea coast (PERSGA 2004).

\section{Mangrove Biochemistry Analysis}

The experimental plant used in this investigation was mangrove; three-leaf samples of each mangrove species from the different plots were selected for sampling and considered three replicates of the same treatment. Multiple leaf samples with mature leaves were collected randomly from each individual by removing each leaf at their abscission zone.

\section{Estimation of Free Proline}

The free proline estimation was made according to the rapid colorimetric procedure described by Bates et al. (1973). These authors described the technique as being adequate for its use in studies regarding water stress. Nonetheless, application to any type of stress has been widely demonstrated, including the less-studied biotic stresses such as allelopathy (Sánchez-Moreiras 1996) and resource competition (Pedrol et al. 1999). Steps of the method: Here, we describe the method for free proline quantification in leaf tissues, which includes four key steps:

Homogenization and filtration: A 250 to 500 mg of fresh leaf tissue (obtained from the youngest fully expanded leaves) is powdered in a cold mortar with liquid nitrogen until pulverization and homogenized with $5 \mathrm{~mL}$ of sulphosalicylic acid $3 \%$ (to get protein precipitation). Then, the homogenate is filtered through a 2 filter paper (e.g., Whatman ${ }^{\circledR}$ n 2 ). The required amount of fresh samples will depend on the tissue's water content.

Reaction with ninhydrin: $2 \mathrm{ml}$ of the filtrated sample are mixed with $2 \mathrm{ml}$ of glacial acetic acid and $2 \mathrm{ml}$ of acid ninhydrin (previously prepared) in test tubes. After agitation, the sample is incubated at $100{ }^{\circ} \mathrm{C}$ for 1 hour, and this produces the colored complex formation. After one hour, the reaction is stopped by putting the tubes in an ice bath.

Extraction: $4 \mathrm{~mL}$ toluene is added to each tube and vortexed for 15-20 s. Then, organic and inorganic phases are separated, obtaining the chromophore dissolved in toluene.

Spectrophotometric measurement: The maximum absorbance of the chromophore when dissolved in toluene is attained at a wavelength of $520 \mathrm{~nm}$. Thus, the organic phase of each sample and standard containing the chromophore is collected, and absorbance at $520 \mathrm{~nm}$ is measured spectrophotometrically.

Calculations and data analysis: Using the data obtained from the standard curve, a linear regression was done (comparing absorbance vs. praline concentration). Thus, we obtain the equation that will allow sample concentration calculations.

\section{Photosynthetic Pigments}

The method used for the quantitative determination of photosynthetic pigments (chlorophylla, chlorophyll-b and carotenoids) was that of Vernon \& Selly (1966). In such a method, $100 \mathrm{mg}$ of explants were cut into small pieces. The pigments were extracted by grinding the cut tissue with a suitable amount of glass powder in a mortar using $100 \mathrm{ml}$ of $80 \%$ aqueous acetone (v. /v.). The homogenate was transferred quantitatively to a $100 \mathrm{ml}$ volumetric flask and mode up to a total volume of $100 \mathrm{ml}$ using $80 \%$ acetone.

The optical density of the extract was measured using a Carl-Zeiss colorimeter at two wavelengths (649 and $665 \mathrm{~nm}$ ). These are positions in the spectrum where maximum absorption by chlorophyll (a) and (b) occurs. 
The concentrations of chlorophyll (a), (b) and total chlorophyll in plant tissue were calculated using the equations mentioned by Vernon \& Selly (1966):

$\mathrm{Mg}$ chlorophyll (a) $/ \mathrm{g}$ tissue $=11.63(\mathrm{~A} 665)-2.39$ (A649).

$\mathrm{Mg}$ chlorophyll (b) $/ \mathrm{g}$ tissue $=20.11(\mathrm{~A} 649)-5.18(\mathrm{~A} 665)$. $\mathrm{Mg}$ chlorophyll $(\mathrm{a}+\mathrm{b}) / \mathrm{g}$ tissue $=6.45(\mathrm{~A} 665)$ +17.72 (A649).

For carotenoids, the concentration was carried according to Lichtentahler (1987) equation: Carx+c $=1000 \times$ OD470- $1.82 \mathrm{Ca}-85.02 \mathrm{Cb} / 198=\mathrm{mg} / \mathrm{g}$

Fresh weight. N.B." A" denotes the reading of optical density

\section{Statistical Analysis}

One-way analysis of variance (ANOVA-1) was used to identify statistically significant differences in biochemical responses (photosynthetic pigments and proline mechanisms) of Avicennia marina and Rhizophora mucronata mangroves to salinity condition using the least significant difference (LSD) test at $\mathrm{P}<0.05$. Statistical analyses were performed using SPSS 15.0 software (SPSS 2006).

\section{Results and discussion}

\section{Free proline}

Mangroves showed variations in proline content between the two species. The means of proline content was indicated in Table (1). It clearly shows that the maximum value of proline content in the present study was recorded $23.56 \mathrm{mg} / \mathrm{g}$ dry wt for R. mucronata at Marsa Sha'ab stands. In addition, the minimum value of proline content was recorded $17 \mathrm{mg} / \mathrm{g}$ dry wt for A. marina at Marsa Sha'ab stands. However, the total mean value of proline was recorded $18.57 \mathrm{mg} / \mathrm{g}$ dry wt for A. marina and $23.98 \mathrm{mg} / \mathrm{g}$ dry wt for R. mucronata. There were highly significant differences in proline content among the two species of mangroves.

The electrical conductivity (EC) of soil extracts ranges from $27.9 \mathrm{ds} / \mathrm{m}$ at Sharm El Madfaa to 51.5 $\mathrm{ds} / \mathrm{m}$ at Marsa Sha'ab (Table 2) with a total mean value of $39.79 \mathrm{ds} / \mathrm{m}$ (Afefe et al. 2020). The present study area "Gebel Elba" considered a hyper-arid area, with seawater salinity recorded 43.95 ppt as the maximum value during the summer months

Table 1. Mean values of proline free (mg/g dry wt) for A. marina and $R$. mucronata

\begin{tabular}{|c|c|c|c|c|c|}
\hline & Sharm EL Madfaa & Marsa Sha'ab & Marsa Abu Fassi & Mean & $\begin{array}{c}\text { LSD } \\
\text { P-value }(0.05)\end{array}$ \\
\hline A. marina & 21.20 & 17.00 & 20.89 & 18.57 & $P=0.547$ \\
\hline R. mucronata & $\begin{array}{c}\text { Marsa Sha'ab } \\
23.56\end{array}$ & \multicolumn{2}{|c|}{ Marsa Abu Fassi } & $\begin{array}{l}\text { Mean } \\
23.98\end{array}$ & $P=0.049$ \\
\hline
\end{tabular}

Table 2. Mean soil electrical conductivity (EC) for A. marina, $R$. mucronata and mixed stands at different locations of the study area

\begin{tabular}{|c|c|c|c|c|c|c|c|}
\hline \multirow{2}{*}{ Character } & \multirow{2}{*}{$\begin{array}{c}\text { Sharm El Madfaa } \\
\text { A. marina }\end{array}$} & \multicolumn{3}{|c|}{ Marsa Sha'ab } & \multicolumn{3}{|c|}{ Marsa Abu Fassi } \\
\hline & & A. marina & R. mucronata & Mixed & A. marina & R. mucronata & Mixed \\
\hline $\mathrm{EC}(\mathrm{ds} / \mathrm{m})$ & 27.9 & 51.5 & 40.3 & 38.2 & 36.6 & 44.5 & 39.5 \\
\hline The mean value & \multicolumn{7}{|c|}{39.79} \\
\hline
\end{tabular}

and recorded $41.04 \mathrm{ppt}$ as the minimum value in the winter months (EEAA 2018).

\section{Photosynthetic Pigments}

\section{Chlorophyll (a)}

Data presented in Table $(3,4,5)$ and Figure $(2,3)$ clearly show that contents of chlorophyll-a in different analyzed mangroves ranged from 4.46 to $6.05 \mathrm{mg} / \mathrm{gf} . \mathrm{wt}$. for A. marina, and from 3.69 to 4.29 $\mathrm{mg} / \mathrm{gf}$.wt. for $R$. mucronata.

\section{Chlorophyll (b)}

Results are shown in Table $(3,4,5)$ and Figure $(2,3)$. The chlorophyll-b content was ranged from 1.46 to $1.83 \mathrm{mg} /$ gf.wt. for $A$. marina, and ranged 
from 1.27 to $1.65 \mathrm{mg} / \mathrm{gf} . \mathrm{wt}$. for $R$. mucronata.

\section{Chlorophyll $(\mathbf{a}+\mathbf{b})$}

Results as shown in Table $(3,4,5)$ and Figure
$(2,3)$ clearly revealed that chlorophyll $(a+b)$ contents varied greatly in A. marina leaves. The contents of chlorophyll $(\mathrm{a}+\mathrm{b})$ in A. marina ranged from 7.88 mg/gf.wt. at Marsa Abu Fassi stands to 5.33

Table 3. Chlorophyll (a, b) and carotenoids content (mg/gf.wt.) in the two species

\begin{tabular}{cccc}
\hline Type of analysis & A. marina & $\boldsymbol{R}$. mucronata & LSD (P-value=0.05) \\
\hline chlorophyll (a) & 5.42 & 3.99 & 0.013 \\
chlorophyll (b) & 1.66 & 1.46 & 0.554 \\
chlorophyll (a + b) & 7.07 & 5.45 & 0.018 \\
Carotenoids & 2.7 & 2.07 & 0.007
\end{tabular}

Table 4. Chlorophyll (a, b) and carotenoids content (mg/gf.wt.) in A. marina

\begin{tabular}{cccccc}
\hline Type of analysis & Sharm EL Madfaa & Marsa Sha'ab & Marsa Abu Fassi & Mean & LSD (P-value=0.05) \\
\hline chlorophyll (a) & 5.74 & 4.46 & 6.05 & 5.42 & 0.122 \\
chlorophyll (b) & 1.69 & 1.46 & 1.83 & 1.66 & 0.026 \\
chlorophyll (a + b) & 7.43 & 5.92 & 7.88 & 7.07 & 0.047 \\
Carotenoids & 2.87 & 2.29 & 2.94 & 2.70 & 0.030 \\
\hline
\end{tabular}

Table 5. Chlorophyll (a, b) and carotenoids content (mg/gf.wt.) in R. mucronata

\begin{tabular}{ccccc}
\hline Type of analysis & Marsa Sha'ab & Marsa Abu Fassi & Mean & LSD (P-value=0.05) \\
\hline chlorophyll (a) & 3.69 & 4.29 & 3.99 & 0.468 \\
chlorophyll (b) & 1.65 & 1.27 & 1.46 & 0.252 \\
chlorophyll (a + b) & 5.33 & 5.56 & 5.45 & 0.928 \\
Carotenoids & 2.04 & 2.09 & 2.07 & 0.935 \\
\hline
\end{tabular}

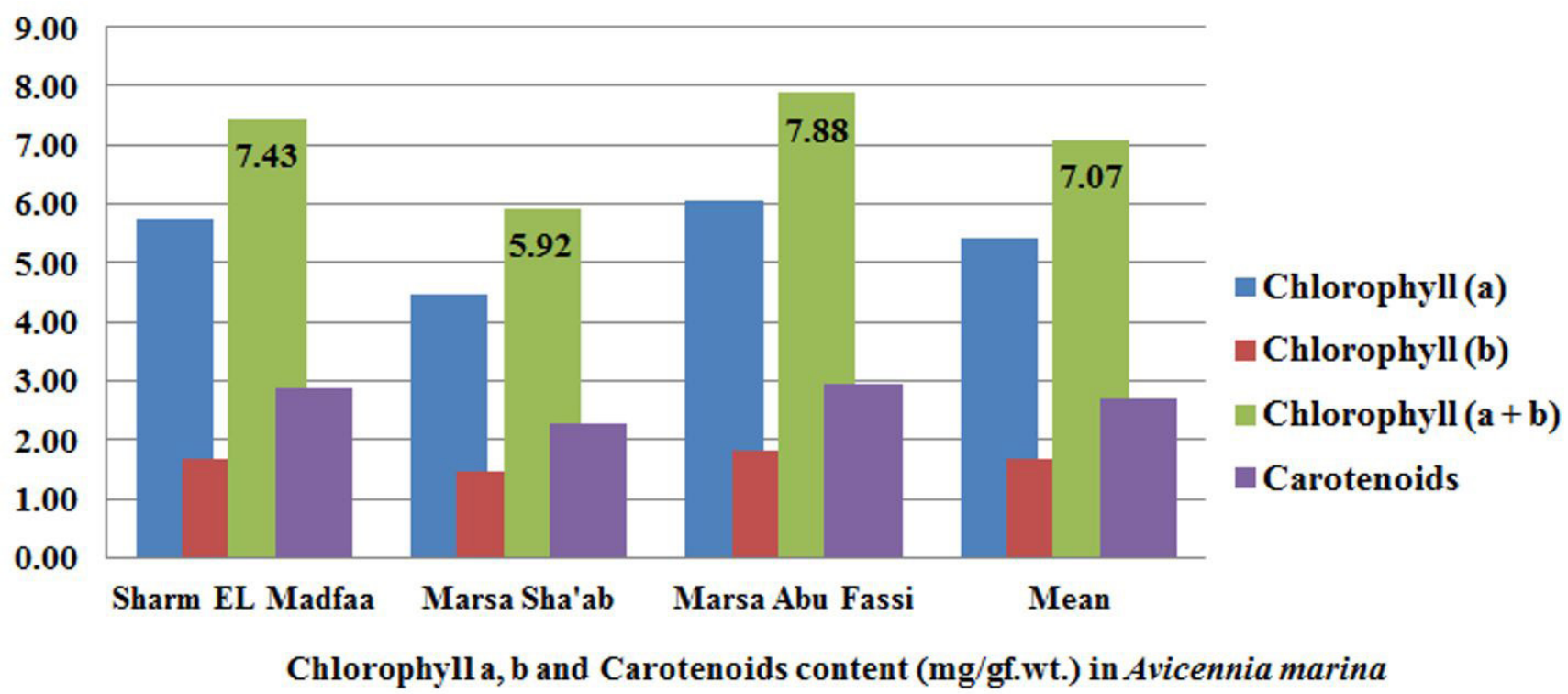

Fig 2. Chlorophyll (a, b) and carotenoids content (mg/gf.wt.) in A. marina 


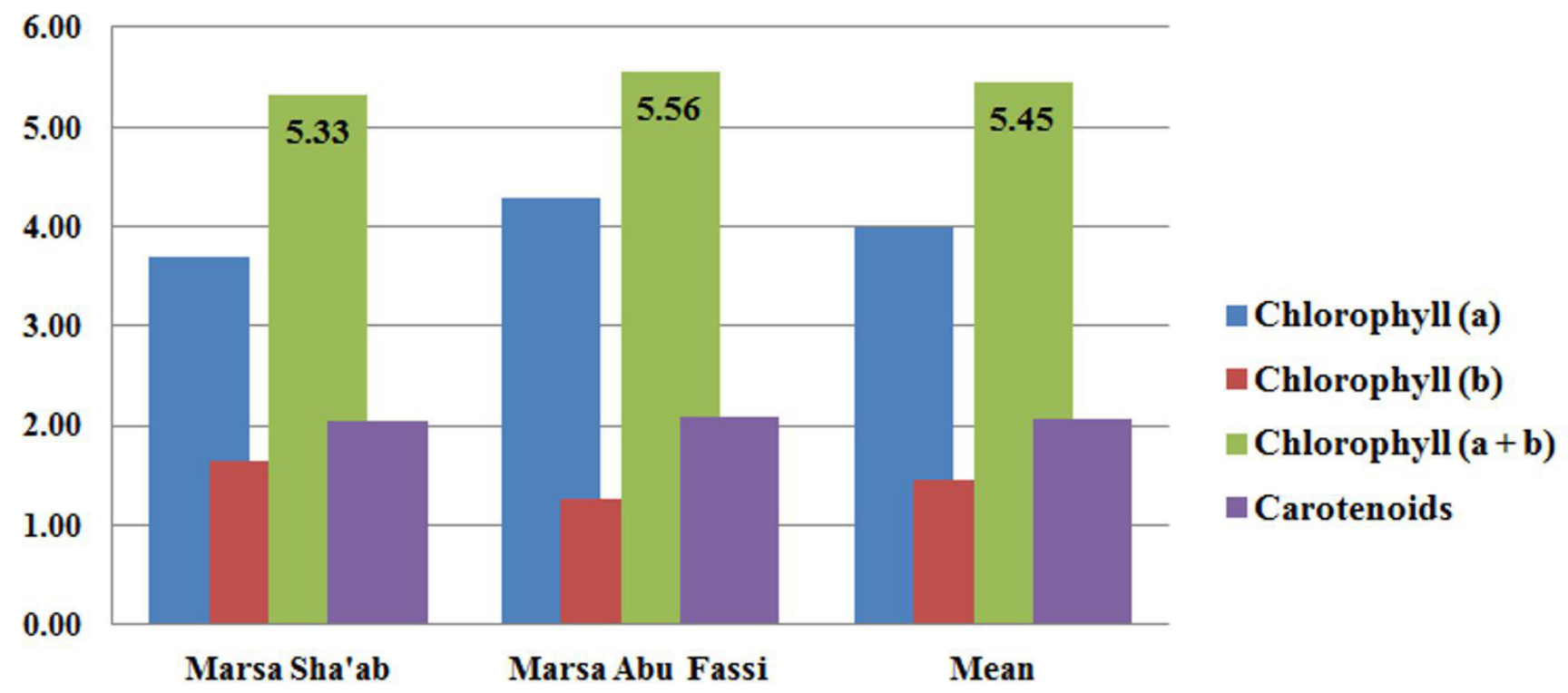

\section{Chlorophyll a, b and Carotenoids content (mg/gf.wt.) in Rhizophora mucronata}

Fig 3. Chlorophyll (a, b) and carotenoids content (mg/gf.wt.) in R. mucronata

mg/gf.wt. at Sharm EL Madfaa stands.

In addition, for $R$. mucronata, the maximum value of chlorophyll $(\mathrm{a}+\mathrm{b})$ was recorded $5.33 \mathrm{mg} /$ gf.wt. at Marsa Abu Fassi stands and the minimum value was recorded $5.56 \mathrm{mg} /$ gf.wt. at Marsa Sha'ab stands.

\section{Carotenoids}

Results shown in Table (3, 4, 5) and Figure (2, 3) clearly revealed that carotenoid contents varied greatly in $A$. marina and $R$. mucronata leaves. The carotenoids content in $A$. marina was ranged from $2.94 \mathrm{mg} / \mathrm{gf} . w \mathrm{t}$. at Marsa Abu Fassi to $2.29 \mathrm{mg} /$ gf.wt. at Marsa Sha'ab. In addition, for R. mucronata, the maximum value of carotenoids content was recorded $2.09 \mathrm{mg} / \mathrm{gf} . \mathrm{wt}$. and the minimum value was recorded 2.04 .

The results reached that the free proline accumulated appreciably in leaves. The functional role of proline accumulation appears to be as a cytoplasmic osmoticum to lower cell water potential, provide hydration to bipolymer and serve as an energy source under high salinity environmental conditions. The mangroves in the current study showed variations in proline content. The maximal value $(23.56 \mathrm{mg} / \mathrm{g}$ dry $\mathrm{wt}$ ) was recorded in $R . m u$ cronata stands, while the minimum value $(17 \mathrm{mg} / \mathrm{g}$ dry wt) was recorded in A. marina stands, and there were highly significant differences among species mangroves from different locations and stands. The mechanism of salt tolerance in mangroves, in particular A. marina, its adaptations for surviving in a saline habitat, physiological characteristics (Biochemical) are peculiar. Many studies dealt with the effects of salinity on mangroves (Patel et al. 2010). High salinity can cause osmotic stress and reduce water availability, resulting in stomatal closure and a reduced supply of carbon dioxide (Li et al., 2008). The ecophysiological significance of salt secretion of A. marina is explained by Waisel et al. (1986). The authors reported that the secretion mechanism is capable of removing only $40 \%$ of the absorbed salts, and the quantitative contribution of the salt glands to the removal of excess salts is relatively small. They further highlighted that the salt resistance of $A$. marina is based upon three different mechanisms: 1) Salt avoidance: where the roots have low permeability to salt; 2) Salt tolerance: the capability to preserve a normal metabolic activity even in the presence of high intracellular salt levels; and 3) Salt evasion-secretion of some of the penetrating ions, but retention of others.

The present study agrees with Ball \& Farquhar (1984a, b) that A. marina tolerates a wider range 
of salinities. A. marina trees secrete excessive salt through glands located on their leaves (Scholander et al. 1962). They can maintain a higher salinity in xylem sap and leaves than other non-secreting mangroves, which enhances their hydraulic conductivity and reduces osmotic potential (Lopez-Portillo et al. 2005). Rhizophora displays a remarkable ability to tolerate extremely low external osmotic potentials (Naidoo 1985). Mangroves regulate the salt content by either excluding it from the roots or secreting salt from the leaves (Scholander et al. 1962). Rhizophora mucronata belongs to the former group and partially excludes salt from the xylem (Atkinson et al. 1967). In addition, $R$. mucronata partially excludes salt at the level of the roots (Scholander et at. 1962).

The current results are in accordance with Patel et al. (2010), who showed that as salinity increases, A. marina increased contents of leaf proline to alleviate $\mathrm{NaCl}$ stress. In addition, salt stress can induce ion toxicities such as membrane disorganization, production of reactive oxygen species, and disturbance of nutrient balance (Hasegawa et al. 2000). In order to defend against salt-induced oxidative damage, plants are equipped with oxygen radical detoxifying enzymes such as superoxide dismutase, peroxidase, and catalase (Ye et al. 2005). The accumulation of inorganic ions in vacuoles is a typical pattern observed in mangrove plants under saline conditions (Naidoo 1987), which serves not only to increase cellular osmolarity to counter osmotic stress but also to avoid increases in ionic strength of the cytoplasm (Dasgupta et al. 2012). Sahoo et al. (2001) studied the accumulation of proline under $\mathrm{NaCl}$ stress of salt-sensitive and salt-tolerant rice cultivars during dark-induced senescence. Salinity significantly enhanced the rate of proline accumulation in the cultivars' senescing leaves, especially in the tolerant cultivars (Sahoo et al. 2001). According to Mondal \& Mondal (2002), the individual amino acid analysis showed an increase in the proline level in the xerophytic sporocarps of Marsilea sp. (Marsileaceae). Proline is involved in several fundamental metabolic reactions associated with the sexual process (Singh \& Chauhan, 1996). Still the concentration of proline often increases under physiological stress, and in such conditions, other amino acids are found to be converted into proline to act as a reservoir of amino acids (Singh \& Chauhan, 1996). Munns (2002) reported that the compounds that accumulate most commonly are proline and glycine betaine. However, other molecules can accumulate to high concentrations in certain species (Munns, 2002).

According to Ashraf \& Harris (2004) proline play an adaptive role in mediating osmotic adjustment and protecting the subcellular structures in stressed plants. Meloni et al. (2004) reported that proline accumulation was not significantly affected by salinity, and in contrary to its generally accepted role in many other species, proline does not seem to play an important role in the mechanism of salt tolerance in Prosopis alba (Fabaceae). Moreover, high salinity was found to reduce the nitrogen accumulation in other mangrove species (Kandelia obovate; Rhizophoraceae) (Kao et al. 2001) It can also inhibit the uptake of $\mathrm{K}^{+}$by $A$. marina, resulting in damage to the photosynthetic apparatus (Patel et al. 2010). On the other hand, during long-term acclimation to saline conditions, mangroves evolve various strategies to cope with high salinity, including anatomical (Cheng et al. 2012) and physiological mechanisms (Dasgupta et al. 2012). Desingh \& Reddy (2005) provided evidence that proline and glycine betaine are known to serve as nitrogen and carbon sources, which can be used during water-limited conditions and while recovering from stress. These compatible solutes are also involved in cell osmoregulation and protection of proteins during dehydration (Rontein et al. 2002; Claussen 2005). However, the significance of proline accumulation in osmotic adjustment is still debated and varies according to the species (Meloni et al., 2004). However, it's apparent that different species of mangroves exhibit different tolerances to salinity stress and the ability to cope with salinity stress may change throughout development (Strasser et al. 2004).

The present study agrees with Long \& Baker (1986) that the salinity can cause a decrease in growth and net photosynthesis of higher plants. This may open the possibility of using photosynthetic parameters in salt-tolerance screening. Maxwell \& Johnson (2000) proved that when a leaf is transferred from darkness into light, PSII reaction centers are progressively closed. This gives rise to an increase in the yield of chlorophyll fluorescence, which can give insights into the plants' ability to tolerate environmental stresses and into the extent to which those stresses have damaged the photosynthetic apparatus Maxwell \& Johnson 2000). 
Physiological distinction: $R$. mucronata is classified as $\mathrm{C} 3$ plants since $\mathrm{CO}_{2}$ is fixated by the use of intermediates that contain three carbon atoms, which is subsequently converted into glucose $\left(\mathrm{C}_{6} \mathrm{H}_{12} \mathrm{O}_{6}\right)$ using the light (Parida \& Jha 2010). One of the major problems associated with using growth as a parameter to measure salinity stress is the necessity for long-term studies to achieve results (Patrick 2006). Leaf stomatal conductance rates in mangroves have been found to be lower than for non-halophytic C3 plants (Hutchings \& Saenger 1987). The rates of photosynthetic $\mathrm{CO} 2$ fixation was found to decline with increasing salinity and this was attributed to stomatal limitations on CO2 uptake (Ball \& Farquhar 1984a; Bjorkman et al., 1988). Teraminami et al. (2013) reported differences in traits between upper and lower leaves: leaves in the upper canopy are typically adapted to high light levels, whereas leaves in the lower canopy exhibit adaptations to low light conditions. The leaves of $R$. mucronata are succulent and shiny white, which facilitate water storage in the mesophyll, while the leaves of $\mathrm{A}$. $\mathrm{ma}$ rina are thinner and covered with several hairs on the abaxial side (Das \& Ghose 1996). The salinity has also been reported to compound the effect of inundation on the physiological tolerance of mangroves seedlings (Ye et al. 2005). In contrast, $A$. marina could only maintain week-long underwater photosynthesis in salinities of up to $66 \%$ seawater (Mwita et al. 2014). The ability to maintain underwater photosynthesis is an important mechanism for avoiding the adverse effects of submergence (Voesenek et al. 2006). A. marina is considered a broad range species in terms of salinity tolerance (Patel et al. 2010).

However, the present study agrees with Hutchings \& Saenger (1987) that the Avicenniacaeae are more tolerant to salinity stress than the Rhizophoraceae. For instance, $A$. marina trees seem to grow well up to $75 \%$ seawater, with a hypothesized growth inhibition at higher salinities due to high sodium chloride $(\mathrm{NaCl})$ concentrations in the tissues (Clough 1984). Seedlings of A. marina exhibited various growth responses under different salinity regimes, with the highest growth recorded at 50\% seawater (17 ppt) and the lowest overall growth under 0 ppt salinity, which was even lower than the growth of seedlings raised in 100\% seawater (35 ppt) (Downtown 1982; Ghowail et al. 1993). These studies suggest that even within a species, salt tol- erance changes depending on the life stage, with seedlings potentially more sensitive to salt stress than mature trees. In comparison, water stress may be the main effect of high salinity on the growth of the Rhizophoraceae (Clough 1984). In Egypt mangroves: Afefe et al. (2019) and El-Khouly \& Khedr (2007) reported that the growth performance of $R$. mucronata was significantly higher in pure stands than in association with $A$. marina, while growing of $A$. marina in association with $R$. mucronata were taller than growing in pure community. Matsuo et al. (2016) reported that tree morphology characterizes the A. marina in per-arid areas on the Red Sea coast, as branches tend to extend laterally rather than upward and often carry adventitious roots on their main axis, where the intrinsic water-use efficiency of leaves can be linked to the actual path length of water transport from water absorptive roots to leaves and that the leaves of these A. marina trees can enhance intrinsic water-use efficiency in response to decreasing hydraulic conductivity of xylem by elongating branches. The lateral branches with adventitious roots may also act to improve the hydraulic conductivity of xylem. These two factors account for the survival of $A$. marina trees growing in per-arid areas along the Red Sea coast. The present study agrees with Zahran \& Willis (2009) that the $A$. marina is relatively more tolerant and adapted to salinity, low rainfall and extreme temperature conditions than $R$. mucronata. This explains the larger local distribution in Egypt of $A$. marina than $R$. mucronata. The latter exists in Egypt only in few localities around the Egyptian-Sudanese border area (PERSGA 2004) and is distributed widely in Africa, Asia, South America, Australia, and Polynesia (Giesen et al. 2006). On the other hand, the current findings agree with Afefe et al. (2019) they suggested that the environmental aspects of mangrove growth in Egypt can be divided into four groups: climatic conditions; geomorphological aspects (Red Sea lagoons, bays and islands); water characteristics and man-made modifications. Moreover, the present study confirms that the mangroves grow under extreme environmental and climatic conditions such as high salinity, temperature and radiation (Moorthy \& Kathiresan 1999). However, the plant life in the Red Sea coastal shoreline and the Eastern Desert in Egypt is rather rich and interesting, where considerations of the exploitation and conservation of natural vegetation must take eco- 
logical principles into account (Afefe 2021). The sustainable management of natural vegetation in Egypt requires stopping the severe human impacts that lead to eliminating certain plant populations and modifying the complex plant communities into simple, fragile ones (Afefe 2020; Abbas et al. 2016; Afefe et al. 2016).

\section{Conclusion}

The mangrove forests are constantly exposed to high salinity, strong winds and high light intensity. In order to survive under harsh conditions, mangroves have many adaptations, including the external and internal structure of the stem, leaf, and flowers and that fruits have undergone considerable changes to suit the environment (Das and Ghose, 1996). The mechanism of salt tolerance in mangroves, particularly A. marina, and their adaptations for surviving in a saline habitat and physiological (biochemical) characteristics are peculiar. This explains why the $A$. marina is relatively more tolerant and adapted to salinity, low rainfall, and extreme temperature conditions than $R$. mucronata. This can also explain why $A$. marina is globally widespread as well in Egypt than $R$. mucronata. The structure of the mangrove ecosystem is determined by the physical and chemical factors of the habitat, and the limit of each species tolerance is determined by its specific environmental requirements such as salinity, temperature, soil feature, $\mathrm{pH}$, electrical conductivity, etc. thus at the seafront $A$. marina and $R$. mucronata are the pioneers. The study of mangrove physiological and biochemical aspects will help us know more about mangrove vegetation. This will help us suggest the remedial measures needed for the proper conservation of the mangrove ecosystem in Egypt and transceiver this knowledge to other countries in the Red Sea and the Middle East region. Moreover, the present study suggests that $R$. mucronata is a highly salt-tolerant species, maintaining its salt balance like a true halophyte though its growth is retarded at very high salinity.

\section{References}

Abbas M., Afefe A., Hatab E., Gaber E. 2016. Vegetation-Soil Relationships in Wadi El-Rayan Protected Area, Western Desert, Egypt. Jordan Journal of Biological Sciences. Volume 9, Number 2, June .2016-
ISSN 1995-6673.

Afefe A. 2020. Composition and changes in the spontaneous flora of the Wadi El Rayan Ramsar site, Fayoum, Egypt, in the last 20 years. Limnological Review, Sciendo. Volume 20: Issue 3.

Afefe A. 2021. Inventory and Conservation of Wild Flora in Gebel Shayeb El-Banat as a Potential Protected Area, the Red Sea Region, Egypt. Aswan University Journal of Environmental Studies (AUJES). Article 2, Volume 2, Issue 1, Winter 2021, Page 11-25

Afefe A., Abbas M., Soliman A., Khedr A., Hatab E. 2020. Tree biomass and soil carbon stocks of a mangrove ecosystem on the Egyptian-African Red Sea coast. Fundamental and Applied Limnology/ E. Schweizerbart'sche Verlagsbuchhandlung. FAL 193, issue 3 .

Afefe A., Abbas M., Soliman A.; Khedr A., Hatab, E. 2019. Physical and chemical characteristics of mangrove soil under marine influence. A case study on the Mangrove Forests at Egyptian-African Red Sea Coast. Egyptian Journal of Aquatic Biology \& Fisheries. Vol. 23(3): $385-399$ (2019).

Afefe A., Hatab E., Abbas M., Gaber E. 2016. Assessment of Threats to Vegetation Cover in Wadi El Rayan Protected Area, Western Desert, Egypt. International Journal of Conservation Science, Volume 7, Issue 3, 2016: 691-708.

Aksornkoae S. 1993. Ecology and Management of Mangroves. IUCN Bangkok, Thailand. pp.35-43.

Alongi D., Chong V., Pfitzner J., Trott L.A., Tirendi F., Dixon P., Brunskill G. 2004. Sediment accumulation and organic material flux in a managed mangrove ecosystem: Estimates of land-ocean-atmosphere exchange in peninsular Malaysia. Mar. Geol., 208: 383-402.

Ashraf M., Harris P. 2004. Potential biochemical indicators of salinity tolerance in plants. Plant Sci., 116: 3-16.

Atkinson M., Findlay G., Hope A., Pitman M., Saddler H., West K. 1967. Salt regulation in the mangroves Rhizophora mucronata Lam. and Aegialitis annulata R. Br. Australian Journal of Biological Sciences. 20: 589 - 699.

Ball M. 1988. Ecophysiology of mangroves. Trees - Structure and Function, 2:129-142

Ball M., Farquhar G. 1984a. Photosynthetic and stomatal responses of two mangrove species, Aegiceras corniculatum and Avicennia marina, to long-term salinity and humidity conditions. Plant Physiology, 74: 1-6.

Ball M., Farquhar G. 1984b. Photosynthetic and stomatal responses of the grey mangrove, Avicennia marina, to transient salinity conditions. Plant Physiol., 74: 7-11.

Bates L., Waldren R., Teare I. 1973. Rapid determination of free proline for water stress studies. Plant Soil, 39:205-207

Bjorkman O., Demming B., Andrews T. 1988. Mangrove photosynthesis: Response to high-irradiance stress. 
Aust. J. Plant Physiol, 15: 43-61.

Bowman. 1917. Ecology and physiology of red mangrove. Proc. Amer. Phil. Soc. 56:589-672.

Cheng H., Wang Y., Ye Z., Chen, D., Wang Y. 2012. Influence of $\mathrm{N}$ deficiency and salinity on metal $(\mathrm{Pb}, \mathrm{Zn}$ and $\mathrm{Cu}$ ) accumulation and tolerance by Rhizophora stylosa in relation to root anatomy and permeability. Environ Pollut, 164: 110-117.

Claussen W. 2005. Proline as a measure of stress in tomato plants. Plant Sci., 168: 241-248.

Clough B. 1984. Growth and salt balance of the mangroves Avicennia marina and Rhizophora stylosa in relation to salinity. Aust. J. Plant Physiol., 11: 419-430.

Das S., Ghose M. 1996. Anatomy of leaves of some mangroves and their associates of Sundarbans, West Bengal. Phytomorphology, 46: 139-150.

Dasgupta N., Nandy P., Sengupta C., Das S. 2012. Protein and enzymes regulations towards salt tolerance of some Indian mangroves in relation to adaptation. Trees, 26: 377-391.

Desingh R., Reddy R. 2005. Differential responses to salinity stress in seedling of three Eucalyptus species. Indian J. Plant Physiol. 10: 307-314.

Downtown W. 1982. Growth and osmotic relations of the mangrove Avicennia marina, as influenced by salinity. Aust. J. Plant Physiol., 9: 519-528.

EEAA. 2018. Environmental data of coastal waters of the Red Sea for 2017, Coastal Water Program, Egyptian Environmental Affairs Agency (first, second, third and fourth) reports.

El-Khouly A., Khedr A. 2007. Zonation Pattern of Avicennia marina and Rhizophora mucronata along the Red Sea Coast, Egypt. World Applied Sciences Journal, 2(4): 283-288.

Gabal Elba Protected Area "GEPA". 2008. Management plan for Elba Protected area. Repot introduced to Nature Conservation Sector, Egyptian Environmental Affairs Agency. EGY/03/17 Elba Protected Area Project. pp. 31.

Ghowail S., Abdel-Monem, A., El-Ghamry W., Saber N. 1993. Preliminary studies on the effects of different salinity levels on germination, growth and anatomy of the mangrove (Avicennia marina). In: Leith $\mathrm{H}$ and Al Massom A (Eds) Towards the Rational use of High Salinity Tolerant Plants, Kluwer Academic Publishers, The Netherlands, pp 237-244.

Gibon Y., Ronan S., Larher F. 2000. Proline accumulation in canola leaf discs subjected to osmotic stress is related to the loss of chlorophylls and to the decrease of mitochondrial activity. Physiol Plantarum, 110:469476

Giesen W., Wulffraat S., Zieren M., Scholten L. 2006. Mangrove guidebook for Southeast Asia. FAO Regional Office for Asia and the Pacific, Bangkok, pp. 539.

Giri C., Ochieng E., Tieszen L., Zhu Z., Singh A., Loveland T., Masek J., Duke N. 2011. Status and distribution of mangrove forests of the world using earth observation satellite data (version 1.3, updated by UNEP-WCMC). Global Ecology and Biogeography, 20: 154-159.

Greenway H., Munns R. 1980. Mechanism of salt tolerance in non-halophytes. Annu. Rev. Plant Physiol., 131: 149-190.

Hasegawa P., Bressan R., Zhu J., Bohnert H. 2000. Plant cellular and molecular responses to high salinity. Annu Rev Plant Physiol Plant Mol Biol, 51: 463-499.

Hutchings P., Saenger P. 1987. Ecology of Mangroves. University of Queensland Press, St Lucia, Australia., 388p.

International Tropical Timber Organization (ITTO). 2006. Egyptian Mangrove Final Report for project of Assessment and Management of Mangrove Forest in Egypt for Sustainable Utilization and Development. Egyptian Environmental Affairs Agency and Ministry of Agriculture and Land Reclamation. pp.65

Kao W., Tsai H., Tsai T. 2001. Effect of $\mathrm{NaCl}$ and nitrogen availability on growth and photosynthesis of seedlings of a mangrove species, Kandelia candel (L.) Druce. J Plant Physiol, 158: 841-846.

Karsten G. 1891. Uber die mangrove-vegetation in Malayischen Archipel. Biblio. Bot. 22:1-71.

Kathiresan K., Bingham B. 2001. Biology of mangroves and mangrove ecosystems. Advances in Marine Biology. 40, 81-251.

Komiyama A., Ong J., Poungparn S. 2008. Allometry, biomass, and productivity of mangrove forests: a review. Aqua. Bot., 89: 128-137.

Li N., Chen S., Zhou X., Li C., Shao J. 2008. Effect of $\mathrm{NaCl}$ on photosynthesis, salt accumulation and ion compartmentation in two mangrove species, Kandelia candel and Bruguiera gymnorrhiza. Aquat Bot, 88: 303-310.

Lichtentahler H. 1987. Chlorophylls and Carotenoids: Pigments of Photosynthetic Biomembranes. Methods in Enzymology 148: 350-382.

Long S., Baker N. 1986. Saline terrestrial environment. In: N.R. Baker and Long, S.P. (Eds.). Photosynthesis in Contrasting Environments. Elsevier, The Netherlands: pp.63-102.

Lopez-Portillo J., Ewers F., Angeles G. 2005. Sap salinity effects on xylem conductivity in two mangrove species. Plant Cell Environ., 28: 1285-1292

Lugo, A.E. 1980. Mangrove ecosystems: successional or steady state, Tropical succession, Biotropica supplement, 12: 65-72.

Matsuo N., Banjo R., Teraminami T., Afefe A., El-Shaffai A., Nakashima A., Nawata H., Yoshikawa K. 2016. Branch Morphology of a Mangrove (Avicennia marina (Forsk.) Vierh) Growing in a Per-Arid Area on the Egyptian Red Sea Coast Regulates Water Use of Its Leaves. Journal of Arid Land Studies. 26-3, 91-94 (2016) https://www.jstage.jst.go.jp/article/ jals/26/3/26_91/_article

Maxwell K., Johnson G. 2000.Chlorophyll fluorescence - 
a practical guide. J. Exp. Bot., 51: 659-668.

Meloni D., Gulotta M., Matinez C., Oliva M. 2004. The effects of salt stress on growth, nitrate reduction and proline and glycine betaine accumulation in Prosopis alba. Braz. J. Plant Physiol., 16: 1-13.

Mondal A., Mondal S. 2002. Biochemical studies on the effects of physiological stress on the sporocarps of Marsilea minuta L. Phytomorphology, 52: 129-138.

Moorthy P., Kathiresan K. 1999. Photosynthetic efficiency in rhizophoracean mangroves with reference to compartmentalization of photosynthetic pigments. Revista de Biologia Tropical, 47: 21-25.

Munns P. 2002. Comparative physiology of salt and water stress. Plant Cell Environ., 25: 239-250.

Mwita M., Matern S., Mats B. 2014. Photosynthetic responses to submergence in mangrove seedlings. Marine and Freshwater Research, 2014, 65, 497-504

Naidoo G. 1985. Responses of the mangrove Rhizophora mucronata to high salinities and low osmotic potentials. S. Afr. J. Bal. 1986, 52: $124-128$.

Naidoo G. 1987. Effects of salinity and nitrogen on growth and plant water relations in the mangrove Avicennia marina (Forssk.) Vierh. New Phytol, 107: 317- 326.

Parida A., Jha B. 2010. Salt tolerance mechanisms in mangroves: a review. Trees-Structure and Function, 24: 199-217.

Patel N., Gupta A., Pandey A. 2010. Salinity tolerance of Avicennia marina (Forssk.) Vierh. from Gujarat coasts of India. Aquatic Botany, 93: 9-16.

Patrick D. Biber. 2006. Measuring the effects of salinity stress in the red mangrove, Rhizophora mangle L. African Journal of Agricultural Research, (1):1-4

Pedrol N., Ramos P., Reigosa M. 1999. Ecophysiology of perennial grasses under water deficits and competition. In Photosynthesis: Mechanisms and Effects. Proceedings of the XIth International Congress on Photosynthesis Vol. V, G. Garab, ed. Dordrecht, The Netherlands, Kluwer Academic Publishers, pp. 102

PERSGA. 2004. Status of Mangroves in the Red Sea and Gulf of Aden. Technical Series Number 11, PERSGA, Jeddah, 67 pp.

Poungparn S., Komiyama A., Sangteian T., Maknual C., Patanaponpaiboon P., Suchewaboripont V. 2012. High primary productivity under submerged soil raises the net ecosystem productivity of a secondary mangrove forest in eastern Thailand. J. Trop. Ecol., 28: 303-306.
Rontein D., Basset G., Hanson A. 2002. Metabolic engineering of osmoprotectnats accumulation in plants. Metab. Engineer, 4: 49-56.

Sahoo S., Sahoo N., Sahu, A. 2001. Sodium chloride stress induced proline accumulation in attached senescing leaves of rice cultivars. Indian J. Plant Physiol., 6: 423-426.

Sánchez-Moreiras A. 1996. Efecto de compuestos fenlicos en Lactuca sativa L. Tesis de Licenciatura. Vigo, Spain: University of Vigo. 14 pp.

Scholander P., Hammel H., Hemmimgsen E., Garey W. 1962. Salt balance in mangrove. Plant Physiol., 37:722- 729.

Singh J., Chauhan S. 1996. Quantitative analysis of free proline in the anthers and pistils of seasonally transient sterile Tecoma stans L. J. Indian Bot. Soc., 75: 117-119.

Spalding M., Kainuma K., Collins L. 2010. World Atlas of Mangroves. A collaborative project of ITTO, ISME, FAO, UNEP-WCMC, UNESCO-MAB, UNU-INWEH and TNC. Earthscan, London. 48 pp.

SPSS. 2006. SPSS Base 15.0 User's Guide. SPSS Inc., Chicago

Suárez N., Sobrado M. 2000. Adjustments in leaf water relations of mangrove (Avicennia germinans) seedlings grown in a salinity gradient. Tree Physiol. 20:277-282.

Teraminami T., Nakashima A., Ominami M., Matsuo N., Nakamura R., Nawata H., Abdelwahab A., ElShaffai A., Yoshikawa K. 2013. Effects of shoot position on shoot and leaf morphology of Avicennia marina in the hyperarid Red Sea coastal region of Egypt. Landscape and Ecological Engineering. 2013, 1-9.

Vernon L., Selly G. 1966.The chlorophylls. Acadimic Press. New York and London. 300 pp.

Voesenek L., Colmer T., Pierik R., Millenaar F., Peeters A. 2006. How plants cope with complete submergence. New Phytologist, 170, 213-226.

Waisel Y., Eshel A., Agami M. 1986. Salt balance of leaves of mangrove Avicennia marina. Physiol. Plant, 67: 67-72.

Ye Y., Tam N., Lu C., Wong Y. 2005. Effects of salinity on germination, seedling growth and physiology of three salt-secreting mangrove species. Aquat Bot, 83: 193-205.

Zahran M., Willis A. 2009. The vegetation of Egypt. Springer, 2nd edition, 437 pp. 